\title{
Comparison of Profitability Proportions before and after the Implementation of Corporate Governance in Companies Listed in Tehran Stock Exchange
}

\author{
Reza Golestani ${ }^{1}$, Reza Fallah ${ }^{1 *}$ \\ ${ }^{1}$ Department of Accounting, Ayatollah Amoli Branch, Islamic Azad University, Amol, IRAN
}

*Corresponding Author: R.Falaha@yahoo.com

Citation: Golestani, R. and Fallah, R. (2019). Comparison of Profitability Proportions before and after the Implementation of Corporate Governance in Companies Listed in Tehran Stock Exchange. Dutch Journal of Finance and Management, 3(1), em0055. https://doi.org/10.29333/djfm/5872

Published: April 3, 2019

\begin{abstract}
The aim of this study was to compare the profitability proportions in companies before and after the use of corporate governance in the companies listed in Tehran Stock Exchange. The research method was descriptive and causal-comparative. The population was all the accepted companies in Tehran Stock Exchange (cars and car fragments, petrochemicals, petroleum products, cement, pharmaceutical, home and sugar appliances) between years of 2010 and 2014 that 82 companies were selected based on Morgan table as a sample. Data was analyzed using independent $\mathrm{t}$-test. Results showed that the average ratio of gross profit to total assets (ROI) in companies after the application of corporate governance had no significant difference with an average ratio of gross profit to total assets (ROI) before the implementation of corporate governance. There was no significant difference between the average ratios of net income to equity (ROE) in companies after the application of corporate governance and net income to equity (ROE) in companies before the application of corporate governance. The average ratio of net profit to total assets (ROA) in companies after the application of corporate governance and average ratio of net profit to total assets (ROA) in companies before the application of corporate governance in companies did not significantly differ from each other. Other results showed that the average ratio of gross profit to total assets (ROI) in companies that used corporate governance had no statistically significant difference with an average ratio of gross profit to total assets (ROI) in companies that did not use corporate governance.
\end{abstract}

Keywords: corporate governance, auditing, profit

\section{INTRODUCTION}

Corporate governance was arisen as mechanisms for dealing with the separation of ownership from control of the commercial unit as well as potential conflicts of representation theory. These mechanisms are assumed as reducing agent in the degree of much difference between the various stakeholders as well as the separation of ownership from controlling the commercial unit (Aghaie et al., 2008). Given the above as well as controlling daily important and key decisions of the commercial unit by professional managers and other regulatory factors, how to control managers by shareholders can be known as one of the main objectives of corporate governance. As well given that it would be expected to reflect the available information quickly in stock prices in efficient capital markets and also entrance of accounting data to the market caused the stock price changes in case that the information would be related to the stock value and has information content (Setayesh and Ebrahimi, 2012). Therefore, company executives are looking for showing financial statements as optimum using a variety of tools 
to change stock prices to show better performance and on the other hand investors are looking for increasing their wealth which would cause a conflict in revenues (Taghavi et al., 2010). The aim of this study was to compare profitability ratios in companies before and after the implementation of corporate governance in firms listed in the Tehran Stock Exchange.

\section{METHODOLOGY}

The research method was descriptive and causal-comparative. The population was all the accepted companies in Tehran Stock Exchange (cars and car fragments, petrochemicals, petroleum products, cement, pharmaceutical, home and sugar appliances) between years of 2010 and 2014. The companies with the following conditions were considered as the sample.

1. Those that their financial period conduces to the end of March.

2. Those that have been accepted in the Tehran Stock Exchange prior to 2013.

3. Those that are not among the mediation, financing, leasing and insurance companies.

4. Those that their needed financial information is available.

5. Those that are not among companies with the initial supply of the stock.

The number of 82 companies was selected as the sample through Morgan table. Following regression model was used to achieve the research goals.

Corporate governance ${ }_{i t}=\alpha_{0}+\alpha_{1} R O I_{i t}+\alpha_{2} R O E_{i t}+\alpha_{3} R O A_{i t}+\alpha_{4} L_{e v} v_{i t}+\alpha_{5} P / E_{i t}+\alpha_{6} S_{i z e_{i t}}+\varepsilon_{i t}$

Corporate governance ${ }_{i t}$ : Corporate governance of companies in the years studied

$R O I_{i t}$ : Return on investment (ROI) ratio in the years studied

$R O E_{i t}$ : Return on owners' equity (ROE) ratio in the years studied

$R O A_{i t}$ : Return on assets (ROA) ratio in the years studied

$L e v_{i t}$ : Financial leverage ratio in the years studied

$P / E_{i t}$ : Price to earnings per share ratio of companies in the years studied

$S_{i z} e_{i t}$ : The size of the companies in the years studied

The research variables were measured as follows.

Profitability index: According to the study of Glen and Singh (2004), the criterion of profitability index may affect the relationship between capital structure and other variables. Profitability indices involve return on investment, return on owner's equity and return on assets that are calculated as follows.

A) Return on investment:

B) Return on equity

$$
R O I_{i t}=\frac{\text { Profit and loss before taxes (gross) }}{\text { Total assets }}
$$

C) Return on total assets

$$
R O E_{i t}=\frac{\text { Profit and loss after taxes (net profit) }}{\text { Equity }}
$$

D) Financial leverage ratio:

$$
R O A_{i t}=\frac{\text { Profit and loss after taxes (net profit) }}{\text { Total assets }}
$$

To calculate the financial leverage ratio of firm $i$ in year $t$, we have (Maquieira, Preve and Sarria-Allende, 2012):

E) Price to earnings per share ratio:

$$
L e v_{i t}=\frac{\text { The book value of total debts }}{\text { The book value of total assets }}
$$

It will be proceeded to calculate the ratio of stock price to earnings per share of the firm $\mathrm{i}$ in year $\mathrm{t}$ as follows.

$$
\text { PEration }_{i t}=\frac{\text { Price per share }}{\text { Earnings per share }}
$$

Off-balance sheet financing of the firm $i$ in year $t$ was measured using rental costs disclosed in the notes to the financial statements of companies listed in Tehran Stock Exchange (Faramarzi and Pormosa, 2014). And sale variable was considered as replaced variable for the size of the company as a controlling factor. Independent $t$-test was used to analyze the data. In all analyzes, the significant level was considered as $\mathrm{p}<0.05$.

\section{RESULTS}

Results of Kolmogorov-Smirnov test showed normal distribution of the data $(p>0.05)$. The average ratio of gross profit to total assets (ROI) in companies after the application of corporate governance was compared with 
Dutch Journal of Finance and Management, 3(1), em0055

Table 1. Results of independent t-test

\begin{tabular}{|c|c|c|c|c|c|c|c|c|c|}
\hline ROI & $\mathbf{N}$ & Mean & $\mathbf{t}$ & df & Sig. & Mean & Std. Deviation & Lower limit & Upper limit \\
\hline Before corporate governance & 18 & 0.2126 & \multirow{2}{*}{0.209} & \multirow{2}{*}{17} & \multirow{2}{*}{0.625} & \multirow{2}{*}{0.00842} & \multirow{2}{*}{0.12659} & \multirow{2}{*}{-0.05259} & \multirow{2}{*}{0.069440} \\
\hline After corporate governance & 18 & 0.2012 & & & & & & & \\
\hline
\end{tabular}

Table 2. Results of independent t-test

\begin{tabular}{|c|c|c|c|c|c|c|c|c|c|}
\hline ROE & $\mathbf{N}$ & Mean & $\mathrm{t}$ & df & sig & Mean & Std. Deviation & Lower limit & Upper limit \\
\hline Before corporate governance & 18 & 0.5116 & 208 & 17 & 0732 & 015579 & 298071 & -128087 & 159245 \\
\hline After corporate governance & 18 & 0.5058 & & & & & & & \\
\hline
\end{tabular}

Table 3. Results of independent t-test

\begin{tabular}{cccccccccc}
\hline ROE & $\mathbf{N}$ & Mean & t & df & sig & Mean & Std. Deviation & Lower limit & Upper limit \\
\hline Before corporate governance & 18 & 0.1819 & -1.709 & 17 & 0.056 & -0.05211 & 0.12017 & \multirow{2}{*}{0.11002} & 0.00581 \\
\hline After corporate governance & 18 & 0.1961 & & & & & & &
\end{tabular}

Table 4. Results of independent t-test

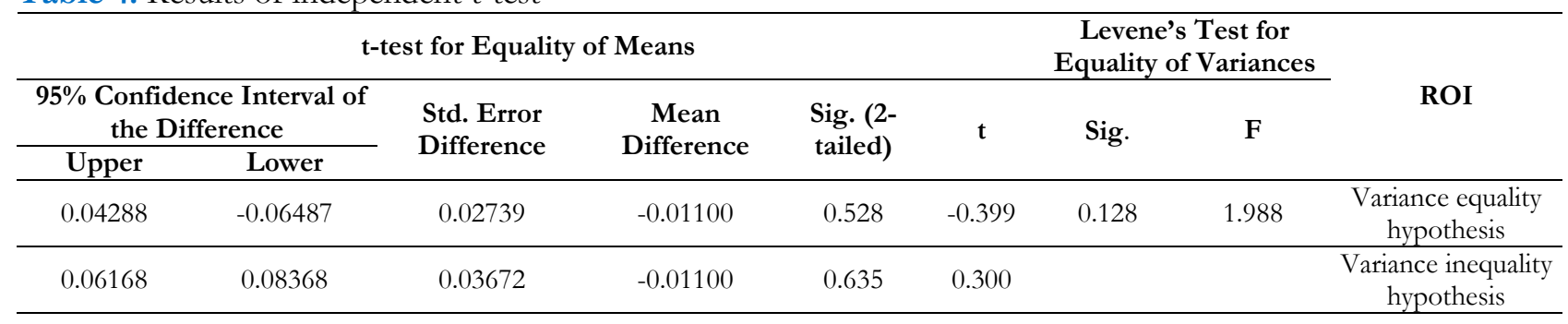

an average ratio of gross profit to total assets (ROI) in companies before the application of corporate governance using independent t-test. Results are presented in Table 1. It can be said that the average ratio of gross profit to total assets (ROI) in companies after the application of corporate governance had no significant difference with an average ratio of gross profit to total assets (ROI) in companies before the implementation of corporate governance.

The average ratio of net profit to equity (ROE) in companies after the application of corporate governance was compared with the average ratio of net profit to equity (ROE) in companies before applying the corporate governance. The results showed that there was no statistically significant difference between the average ratio of net profit to equity (ROE) in companies after the application of corporate governance and average ratio of net income to equity (ROE) in companies before the application of corporate governance (Table 2).

The average ratio of net profit to total assets (ROA) in companies after the application of corporate governance was compared with average ratio of net profit to total assets (ROA) in companies before applying the corporate governance. It can be said that the average ratio of net profit to total assets (ROA) in companies after the application of corporate governance and average ratio of net profit to total assets (ROA) in companies before the application of corporate governance had no significant difference with each other (Table 3).

The average ratio of gross profit to total assets (ROI) in companies that used corporate governance was compared with an average ratio of gross profit to total assets (ROI) in companies that did not use corporate governance. Results showed that the average ratio of gross profit to total assets (ROI) in companies using corporate governance had no significant difference with an average ratio of gross profit to total assets (ROI) in companies not using corporate governance (Table 4).

\section{DISCUSSION AND CONCLUSION}

The aim of this study was to compare profitability ratios in companies before and after the implementation of corporate governance in firms listed in the Tehran Stock Exchange. Results showed that the average ratio of gross profit to total assets (ROI) in companies after the application of corporate governance had no significant difference with an average ratio of gross profit to total assets (ROI) in companies before the implementation of corporate governance. There was no significant difference between the average ratios of net profit to equity (ROE) in companies after the application of corporate governance and before the application of corporate governance. The average ratio of net profit to total assets (ROA) in companies after the application of corporate governance did not differ significantly with an average ratio of net income to total assets (ROA) in companies before the application of corporate governance. Other results showed that the average ratio of gross profit to total assets (ROI) in companies that used corporate governance had no significant difference with an average ratio of gross profit to total assets (ROI) in companies that didn't use corporate governance. Results of previous studies showed 
that the implementation of corporate governance involves a set of relationships between shareholders, directors, auditors and other stakeholders that ensure holding controlling system in order to respect the rights of shareholders as well as the proper implementation of the decisions of the assembly and prevention of possible abuses. Corporate governance is arisen as a mechanism for dealing with the separation of ownership from control of the commercial unit as well as potential conflicts of representation theory. These mechanisms are assumed as reducing agent in the degree of much difference between the various stakeholders as well as the separation of ownership from controlling the commercial unit. As discussed above, negative relationship between corporate governance and future stock returns that is caused due to inexperienced investors in the market and by the conducted examination in the sample studied, the use of corporate governance by the companies has been confirmed in the market and continually it has examined this issue that inexperienced investors demonstrate incorrect response to the application of corporate governance affected by what factor. The use of corporate governance is known as an incorrect reaction of investors, this factor was examined that suggesting that as more companies are adopting corporate governance, efficiency of financial ratios and profitability ratios does not significantly change. This may be due to not to desirable use of corporate governance tools by firms listed in the Tehran Stock Exchange, restrictions on the use of corporate governance tools, how to choose the statistical community and other factors such as the effects of hyperinflation in the economy of the country which increases the cost of rent in accordance with inflation faster and thus will reduce the profitability.

\section{REFERENCES}

Aghaie, M. A., Etemadi, H., Azar, A. and Chalaki, P. (2009). Features of corporate governance and information content of profit in the Tehran Stock Exchange with emphasis on the role of earnings management of profit. Journal of Iranian management sciences, 4(16), 27-53.

Faramarzi, J. and Pormosa, A. (2014). Study of the impact of off-balance sheet financing on equity in the firms listed in the Tehran Stock Exchange. Quarterly journal of accounting science and management auditing, 3(12).

Glen, J. and Singh, A. (2004). Comparing capital structures and rates of return in developed and emerging markets. Emerging Markets Review, 5, 161-192. https://doi.org/10.1016/j.ememar.2004.01.001

Maquieira, C. P., Preve, L. A. and Sarria-Allende, V. (2012). Capital budgeting, cost of capital and capital structure: and distinctive features in Latin America. Emerging markets review, 13, 118-148. https://doi.org/10.1016/j.ememar.2011.11.001

Setayesh, M. H. and Ebrahimi, F. (2012). Examination of the impact of corporate governance mechanisms on information content of profits of firms listed in the Tehran Stock Exchange. Accounting knowledge, 3(8), 31-48.

Taghavi, M., Esmailzadeh-maghari, E., Ahmad-sherbafi, M. and Zamanian, A. (2010). Evaluation of off-balance sheet financing method (operating lease) on the stock price and profit of the firms listed in the Tehran Stock Exchange. Journal of quantitative studies in management, 2, 98-109. 